\title{
Microstructures and tensile properties of as-cast Mg-5Sn-1Si magnesium alloy modified with trace elements of $\mathrm{Y}, \mathrm{Bi}, \mathrm{Sb}$ and $\mathrm{Sr}$
}

\author{
He-shuai $\mathbf{Y u}^{1,2}$, ${ }^{*}$ Xue-feng Guo ${ }^{1,2}$, Hong-bao Cui ${ }^{1,2}$ \\ 1. School of Materials Science and Engineering, Henan Polytechnic University, Jiaozuo 454000, Henan, China \\ 2. Henan International Joint Research Laboratory for High-Performance Light Metallic Materials and Numerical Simulations, \\ Henan Polytechnic University, Jiaozuo 454000, Henan, China
}

\begin{abstract}
The microstructures and mechanical properties of as-cast Mg-5Sn-1Si magnesium alloy modified with trace elements $\mathrm{Y}, \mathrm{Bi}, \mathrm{Sb}$ and $\mathrm{Sr}$ were investigated and compared. Results show that the microstructure of the as-cast $\mathrm{Mg}-5 \mathrm{Sn}-1 \mathrm{Si}$ alloy consists of $\alpha-\mathrm{Mg}, \mathrm{Mg}_{2} \mathrm{Si}, \mathrm{Mg}_{2} \mathrm{Sn}$ and $\mathrm{Mg}_{2}\left(\mathrm{Si}_{x} \mathrm{Sn}_{1-x}\right)$ phases. After adding $0.8 w t . \% \mathrm{Y}$, $0.3 w t . \% \mathrm{Bi}, 0.9$ wt. $\% \mathrm{Sb}$ and 0.9 wt.\% Sr, respectively into the Mg-5Sn-1Si magnesium alloy, $\mathrm{Mg}_{24} \mathrm{Y}_{5}, \mathrm{Mg}_{3} \mathrm{Bi}_{2}$, $\mathrm{Mg}_{3} \mathrm{Sb}_{2}$ and $\mathrm{Mg}_{2} \mathrm{Sr}$ phases are precipitated accordingly. Trace elements can refine $\alpha-\mathrm{Mg}$ grain and Chinese scriptshaped $\mathrm{Mg}_{2} \mathrm{Si}$ phase. Refinement efficiency of different trace elements on $\alpha-\mathrm{Mg}$ grain and $\mathrm{Mg}_{2} \mathrm{Si}$ phase is varied. $\mathrm{Sr}$ element has the best refinement effect, followed by $\mathrm{Sb}$ and $\mathrm{Bi}$, while $\mathrm{Y}$ has the least refinement effect. Mg-5Sn$1 \mathrm{Si}-0.9 \mathrm{Sr}$ alloy has higher tensile properties than the other three modified alloys. The refinement mechanism of $\mathrm{Y}$, $\mathrm{Bi}$ and $\mathrm{Sr}$ elements on $\mathrm{Mg}-5 \mathrm{Sn}-1 \mathrm{Si}$ magnesium alloy can be explained by the growth restriction factors and the solute undercooling. For Mg-5Sn-1Si-0.9Sb alloy, the heterogeneous nuclei of $\mathrm{Mg}_{3} \mathrm{Sb}_{2}$ phase is the main reason for the refinement of grains and second phases.
\end{abstract}

Key words: magnesium alloy; Mg-5Sn-1Si alloy; Y, Bi, Sb, Sr; $\mathrm{Mg}_{2} \mathrm{Si}$ phase

CLC numbers: TG146.22Ｄocument code: A Article ID: 1672-6421(2021)01-009-09

\section{Introduction}

As the lightest metallic engineering materials, magnesium alloys have received a great attention in recent years due to their several advantages such as high strength-to-weight ratio, high thermal conductivity, high dimensional stability, good electromagnetic shielding characteristics, high damping capacity and good machineability ${ }^{[1-3]}$. However, commercial cast magnesium alloys such as AZ and AM alloys are limited in some applications because of their poor creep resistances and mechanical properties at elevated temperatures over $120^{\circ} \mathrm{C}$. This is caused by the lowmelting-point of $\mathrm{Mg}_{17} \mathrm{Al}_{12}$ phase which precipitates at grain boundaries during solidification ${ }^{[4-6]}$. Hence, in the last decade, improving elevated temperature properties of magnesium alloys has become a critical issue. In order

\section{*Xue-feng Guo}

Male, born in 1962, Professor. He is mainly engaged in the research and development of microstructure and properties of heat-resistant magnesium alloys, rapidly solidified magnesium alloys and deformed magnesium alloys. To date, he has published 4 books and more than 200 papers.

E-mail: guoxuef@hpu.edu.cn;

Received: 2020-08-21; Accepted: 2020-10-28 to overcome or minimize the deterioration of $\mathrm{Mg}_{17} \mathrm{Al}_{12}$ phase on high-temperature mechanical properties, new alloys were developed and investigated, for example, $\mathrm{Mg}-\mathrm{Al}-\mathrm{RE}{ }^{[7]}, \mathrm{Mg}-\mathrm{Zn}-\mathrm{Y}-\mathrm{Ce}{ }^{[8,9]}, \mathrm{Mg}-\mathrm{Sn}-\mathrm{Ca}{ }^{[10]}$ and $\mathrm{Mg}-\mathrm{Gd}^{[11]}$ system alloys. It was found that $\mathrm{Mg}-\mathrm{Si}$ based alloys are potentially elevated temperature magnesium alloys because $\mathrm{Mg}_{2} \mathrm{Si}$ phase in $\mathrm{Mg}$-Si based alloys has high melting point, high hardness, low density (similar to $\mathrm{Mg}$ alloy), high elastic modulus and low thermal expansion coefficient. Moreover, $\mathrm{Mg}_{2} \mathrm{Si}$ phase is very stable and can impede grain boundary sliding at elevated temperatures ${ }^{[12-14]}$. Whereas, under low solidification rates, $\mathrm{Mg}_{2} \mathrm{Si}$ phase precipitates from $\mathrm{Mg}$-Si-based melt in a coarse Chinese script-shaped form, which has proved to be very damaging to the mechanical properties of the alloys. The reasons for deteriorating mechanical properties of the $\mathrm{Mg}$-Si alloys are related to the sharp corners and the brittleness of the coarse $\mathrm{Mg}_{2} \mathrm{Si}$ compound, as well as the poor $\alpha-\mathrm{Mg} /$ $\mathrm{Mg}_{2} \mathrm{Si}$ interfacial adhesion ${ }^{[15]}$. Therefore, modifying and refining $\mathrm{Mg}_{2} \mathrm{Si}$ phase, and improving the $\alpha-\mathrm{Mg} /$ $\mathrm{Mg}_{2} \mathrm{Si}$ interfacial adhesion are thought to be the key factors to enhance the mechanical properties of Mg-Si based alloys. 
At present, there are many ways to enhance the strength of magnesium alloys at room and high temperatures, in which the most fundamental and effective methods are element alloying and deformation ${ }^{[16]}$. Alloying elements such as $\mathrm{Sr}^{[17,18]}, \mathrm{P}^{[19]}, \mathrm{Bi}^{[20]}$, $\mathrm{Y}^{[21]}, \mathrm{Sb}^{[22-24]}, \mathrm{La}^{[25]}, \mathrm{Nd}^{[26]}, \mathrm{Gd}^{[27]}$ and compound $\mathrm{KBF}_{4}{ }^{[28]}$ have positive modification effects on the morphology of $\mathrm{Mg}_{2} \mathrm{Si}$ phase. In general, trace alloying elements only change the morphologies of the constituent phases during solidification, and cannot change their inherent structures. Therefore, adding trace elements to $\mathrm{Mg}$-Si alloys is considered a useful method to modify and refine the morphology of $\mathrm{Mg}_{2} \mathrm{Si}$ phase. Considering that $\mathrm{Si}, \mathrm{Ge}, \mathrm{Sn}$ and $\mathrm{Pb}$ belong to the same group, i.e. IVA group, and that they all can form the same anti- $\mathrm{CaF}_{2}$ crystal structure $\mathrm{Mg}_{2} X(X=\mathrm{Si}, \mathrm{Ge}, \mathrm{Sn}$ or $\mathrm{Pb})$ with magnesium, the $\mathrm{Mg}_{2} X$ is considered a linear compound with an Fm-3m space group. These $\mathrm{Mg}_{2} \mathrm{X}$ compounds may have certain solubility to each other, as is known, $\mathrm{Mg}_{2} \mathrm{Si}$ and $\mathrm{Mg}_{2} \mathrm{Sn}$ have certain solubility to each other at least. Thus, the mechanical properties and $\alpha-\mathrm{Mg} / \mathrm{Mg}_{2} X$ interfacial adhesion of the alloys could be changed whether being improved or deteriorated. It has been revealed that $\mathrm{Mg}_{2} \mathrm{Si}$ and $\mathrm{Mg}_{2} \mathrm{Sn}$ have almost the same lattice constants $\left(\mathrm{Mg}_{2} \mathrm{Si}\right.$ is $0.633 \mathrm{~nm}, \mathrm{Mg}_{2} \mathrm{Sn}$ is $\left.0.699 \mathrm{~nm}\right)$ and have some solubility to each other by $\mathrm{Sn}$ and $\mathrm{Si}$ replacement to each other. $\mathrm{Mg}_{2} \mathrm{Sn}$ phase can dissolve 3at.\%-14at.\% Si, $\mathrm{Mg}_{2} \mathrm{Si}$ can dissolve 2at.\%-13.3at.\% Sn. Wang's ${ }^{[15]}$ calculations indicate that a new reinforcement phase $\mathrm{Mg}_{2}\left(\mathrm{Si}_{x} \mathrm{Sn}_{1-x}\right)$ forms by a substitution reaction in the $\mathrm{Mg}-\mathrm{Si}-\mathrm{Sn}$ alloys, and there are a certain percentage of covalent bonds in $\mathrm{Mg}_{2}\left(\mathrm{Si}_{x} \mathrm{Sn}_{1-x}\right)$, which ensure $\mathrm{Mg}_{2}\left(\mathrm{Si}_{x} \mathrm{Sn}_{1-x}\right)$ has sufficient hardness to act as a reinforcement phase and exhibits greater ductility than that of the unalloyed $\mathrm{Mg}_{2} \mathrm{Si}$ phase. If some $\mathrm{Sn}$ atoms replace equivalent $\mathrm{Si}$ atoms from $\mathrm{Mg}_{2} \mathrm{Si}$ phase, the value of interfacial adhesion work (Wad) between $\alpha-\mathrm{Mg}$ matrix and the $\mathrm{Mg}_{2}\left(\mathrm{Si}_{\mathrm{x}} \mathrm{Sn}_{1-\mathrm{x}}\right)$ compound increases, then, the poor interfacial adhesion between $\alpha-\mathrm{Mg}$ and unalloyed $\mathrm{Mg}_{2} \mathrm{Si}$ phase is improved. Hence, it is reasonable to speculate that simultaneously adding $\mathrm{Sn}$ and other trace elements to Mg-Si alloys can improve the mechanical properties of the Mg-Si alloys. Accordingly, selecting suitable trace elements which can modify and refine the morphology of $\mathrm{Mg}_{2} \mathrm{Si}$ phase in $\mathrm{Mg}$-Sn-Si based alloy appears to be very important for further research.

Liu et al. ${ }^{[29]}$ studied the microstructures, tensile properties, and creep behaviour of as-cast Mg-(1-10)wt.\% Sn alloys, and found that $\mathrm{Mg}-5 \mathrm{wt} . \% \mathrm{Sn}$ alloy has the best mechanical performance at room and elevated temperatures. Jiang et al. ${ }^{[21]}$ studied the effect of $\mathrm{Y}$ on modification of $\mathrm{Mg}_{2} \mathrm{Si}$ in $\mathrm{Mg}-\mathrm{Si}$ alloys and indicated that when the $\mathrm{Y}$ content is $0.1 \mathrm{wt} . \%$ or $0.4 \mathrm{wt} . \%$, the sizes of primary and eutectic $\mathrm{Mg}_{2} \mathrm{Si}$ do not significantly reduce. When the $\mathrm{Y}$ content is $0.8 \mathrm{wt} . \%$, the mean size of $\mathrm{Mg}_{2} \mathrm{Si}$ particles decreases from more than $100 \mu \mathrm{m}$ to about $30 \mu \mathrm{m}$ or less; however, with the further increase of the $\mathrm{Y}$ content to $1.2 \mathrm{wt} . \%$, the primary $\mathrm{Mg}_{2} \mathrm{Si}$ becomes coarser again and even larger than that in the unmodified alloy. Ma et al. ${ }^{[30]}$ investigated the influence of trace $\mathrm{Y}$ element on the microstructure of $\mathrm{Mg}$ $5 \mathrm{Sn}-1 \mathrm{Si}$ alloy and found that when the $\mathrm{Y}$ content is $0.8 \mathrm{wt} . \%$, the modification effect of $\mathrm{Y}$ on the microstructure of the alloy is excellent. Guo et al. ${ }^{[20]}$ studied the modification of $\mathrm{Mg}_{2} \mathrm{Si}$ morphology in Mg-Si alloys with Bi element and found that the optimal modification effect is obtained when the Bi content is no more than $0.5 \mathrm{wt} . \%$. Yan et al. ${ }^{[31]}$ researched the influence of $\mathrm{Sb}$ modification on microstructure and mechanical properties of $\mathrm{Mg}_{2} \mathrm{Si} / \mathrm{AM} 60$ composite and indicated that $\mathrm{Mg}_{3} \mathrm{Sb}_{2}$ can promote the formation of fine polygonal type $\mathrm{Mg}_{2} \mathrm{Si}$ by providing a nucleation site, and the ultimate tensile strength is enhanced by $12.2 \%$ with the addition of $0.8 \mathrm{wt} . \% \mathrm{Sb}$. Wang et al. ${ }^{[32]}$ proved that after adding $0.9 \mathrm{wt} . \% \mathrm{Sb}$ into $\mathrm{Mg}-5 \mathrm{Sn}-1 \mathrm{Si}$ alloy, the arm spacing of $\mathrm{Mg}_{2} \mathrm{Si}$ phase is decreased. Cong et al. ${ }^{[33]}$ investigated the effect of $\mathrm{Sr}$ on microstructure of as-cast $\mathrm{Mg}-6 \mathrm{Zn}-4 \mathrm{Si}$ alloy and found that the grain size of the primary $\mathrm{Mg}_{2} \mathrm{Si}$ decreased initially and then gradually increased with increasing $\mathrm{Sr}$ amount, and the optimal mechanical properties and wear resistance could be obtained by a Sr addition of $0.5 \mathrm{wt} . \%$.

Based on the above discussion and published research results, in this present work, the effects of trace elements: $0.8 \mathrm{wt} . \% \mathrm{Y}$, 0.3 wt. $\%$ Bi, 0.9 wt. $\% \mathrm{Sb}$ and $0.9 \mathrm{wt} . \% \mathrm{Sr}$ on microstructure and mechanical properties of cast $\mathrm{Mg}-5 \mathrm{Sn}-1 \mathrm{Si}$ magnesium alloy were investigated, and the modification and refinement results of $\alpha-\mathrm{Mg}$ grain and $\mathrm{Mg}_{2} \mathrm{Si}$ phase were compared.

\section{Experimental procedure}

The nominal compositions of Mg-5Sn-1Si based alloys used in this study are presented in Table 1. The investigated materials were prepared with a resistance furnace by melting pure $\mathrm{Mg}$ (>99.90\%), Sn (>99.99\%), Bi (>99.99\%), Sb (>99.99\%) and master alloys of $\mathrm{Mg}-5.0 \% \mathrm{Si}, \mathrm{Mg}-10 \% \mathrm{Sr}$ and $\mathrm{Mg}-30.0 \% \mathrm{Y}$ in a steel crucible. Before melting, all of the raw materials were preheated to $120^{\circ} \mathrm{C}$ to remove the surface moisture. The pure $\mathrm{Mg}$ ingots were firstly put into the steel crucible and heated to $720{ }^{\circ} \mathrm{C}$ with protection of mixture gas of $0.5 \mathrm{vol} . \%$ SF 6 and 99.5 vol. $\% \mathrm{CO}_{2}$. When the pure $\mathrm{Mg}$ ingots were completely melted, the preheated $\mathrm{Sn}, \mathrm{Bi}, \mathrm{Sb}, \mathrm{Mg}-30.0 \% \mathrm{Y}, \mathrm{Mg}-10 \% \mathrm{Sr}$ and $\mathrm{Mg}-5.0 \% \mathrm{Si}$ master alloys were respectively added into the $\mathrm{Mg}$ melt. Then the temperature was raised to $780{ }^{\circ} \mathrm{C}$ and held for 30 min to ensure the $\mathrm{Mg}-5.0 \% \mathrm{Si}$ master alloy being completely melted. During holding period, the melts were stirred with a carbon bar for several times in order to melt the $\mathrm{Mg}-5.0 \% \mathrm{Si}$ master alloy completely and make the compositions of the melts uniform. Then, the melts were cast into ingots with a diameter of $105 \mathrm{~mm}$ and a length of $450 \mathrm{~mm}$. In order to analyze the microstructures of the alloys, the as-cast metallographic samples were prepared in accordance with the standard routines and etched with picric acid solution $(5 \mathrm{~g}$ picric acid $+10 \mathrm{~mL}$ glacial acetic $+10 \mathrm{~mL}$ distilled water $+80 \mathrm{~mL}$ anhydrous ethanol) for 5-10 $\mathrm{s}$ at room temperature. Microstructural analysis was conducted by using an optical microscope (OM, Olympus GX51) and a scanning electron microscope (SEM, JSM$6700 \mathrm{~F}$ ) equipped with an energy dispersive X-ray spectrometer (Oxford, Germany). The phases of the alloys were analyzed by using X-Ray diffraction (XRD, Rigaku D/max-3C type, 
Japan), the radiation source was $\mathrm{Cu} \mathrm{K} \alpha$, scanning step and range were $0.033^{\circ}$ and $10^{\circ}-90^{\circ}$, respectively. Thermal analysis by differential scanning calorimetry (DSC) were performed using a NETZSCH STA 2500 system. For the DSC tests, samples weighed around $20 \mathrm{mg}$ were heated under flowing argon atmosphere from room temperature to $750{ }^{\circ} \mathrm{C}$. The heating curves were recorded at a controlling speed of $5^{\circ} \mathrm{C} \cdot \mathrm{min}^{-1}$. The tensile properties at room temperature were determined from the stress-strain curves. The $0.2 \%$ yield strength (YS), ultimate tensile strength (UTS) and elongation to failure were obtained based on the average results of three valid tests.

Table 1: Nominal compositions of experimental Mg-5Sn-1Si alloys (wt.\%)

$\begin{array}{cccccccc}\text { Alloys } & \text { Sn } & \text { Si } & \text { Y } & \text { Bi } & \text { Sb } & \text { Sr } & \text { Mg } \\ 1 & 5.30 & 1.32 & - & - & - & - & \text { Bal. } \\ 2 & 5.39 & 1.36 & 0.81 & - & - & - & \text { Bal. } \\ 3 & 5.35 & 1.37 & - & 0.32 & - & - & \text { Bal. } \\ 4 & 5.32 & 1.34 & - & - & 0.88 & - & \text { Bal. } \\ 5 & 5.38 & 1.35 & - & - & - & 0.89 & \text { Bal. }\end{array}$

\section{Results and discussion}

\subsection{Microstructure of as-cast Mg-5Sn-1Si alloy}

Figure 1 presents the XRD pattern of the Mg-5Sn-1Si alloy. It indicates that this alloy consists of $\alpha-\mathrm{Mg}, \mathrm{Mg}_{2} \mathrm{Si}$ and $\mathrm{Mg}_{2} \mathrm{Sn}$ phases. The corresponding SEM images of the as-cast $\mathrm{Mg}$ 5Sn-1Si alloy are presented in Fig. 2. It can be observed that the matrix of the alloy is $\alpha-\mathrm{Mg}$ solid solution and the others are secondary phases with different morphologies which spread on the matrix and inter-dendritic regions. The inter-dendrite compounds have two morphologies: one is in Chinese script and another in irregular-shape which is abnormal eutectic phase. Combining the EDS (Table 2) and XRD results, it can be proved that the abnormal eutectic compounds (Point 1 in Fig. 2) which enrich in $\mathrm{Mg}$ and $\mathrm{Sn}$ and minor Si elements are $\mathrm{Mg}_{2} \mathrm{Sn}$ phase. The compound in Chinese script morphology which locates at the grain boundary has the typical characteristics of $\mathrm{Mg}_{2} \mathrm{Si}$ phase. EDS results show that the compound at the boundries of $\mathrm{Mg}_{2} \mathrm{Si}$ phase is much different from the main part of the $\mathrm{Mg}_{2} \mathrm{Si}$. It contains a certain amount of Sn element, so it is a new phase $\mathrm{Mg}_{2}\left(\mathrm{Si}_{x} \mathrm{Sn}_{1-x}\right)$. Therefore, the as-cast Mg-
5Sn-1 Si alloy consists of $\alpha-\mathrm{Mg}$, abnormal eutectic $\mathrm{Mg}_{2} \mathrm{Sn}$ phase, Chinese-character $\mathrm{Mg}_{2} \mathrm{Si}$ phase at grain boundaries, and some ternary $\mathrm{Mg}_{2}\left(\mathrm{Si}_{x} \mathrm{Sn}_{1-x}\right)$ compounds as well. The ternary $\mathrm{Mg}_{2}\left(\mathrm{Si}_{x} \mathrm{Sn}_{1-x}\right)$ compound is at the boundaries of the $\mathrm{Mg}_{2} \mathrm{Si}$ phase. Under low solidification rate, the $\mathrm{Mg}_{2} \mathrm{Si}$ phase tends to grow into the Chinese script form in $\mathrm{Mg}-5 \mathrm{Sn}-1 \mathrm{Si}$ alloy, which is detrimental to the mechanical properties of the alloys.

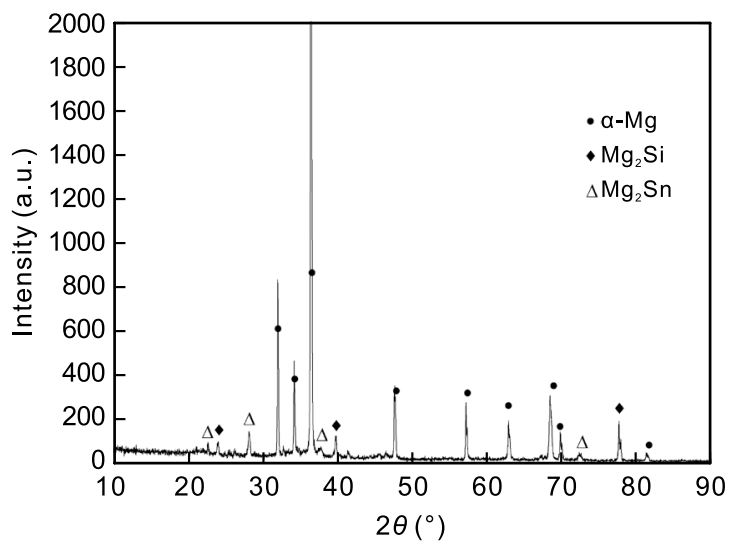

Fig. 1: XRD pattern of as-cast Mg-5Sn-1Si alloy

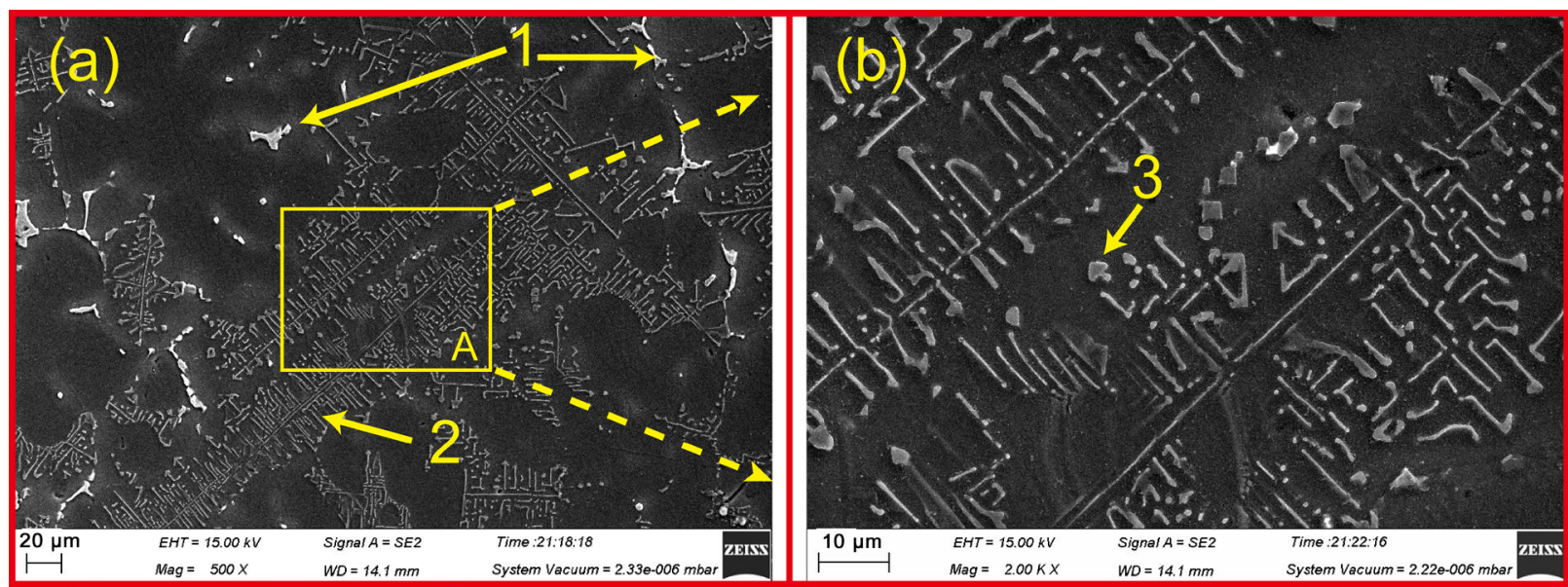

Fig. 2: (a) SEM images of as-cast Mg-5Sn-1Si alloy; (b) SEM image with higher magnification of Zone A in (a) 
Table 2: EDS results of phases in as-cast Mg-5Sn-1Si alloy (wt.\%)

\begin{tabular}{|cccc|} 
Points in Fig. 2 & Mg & Sn & Si \\
\hline 1 & 34.12 & 63.99 & 1.89 \\
2 & 59.38 & 11.47 & 29.15 \\
3 & 82.73 & 6.12 & 11.15 \\
\hline
\end{tabular}

\subsection{Microstructures of modified Mg-5Sn-1Si magnesium alloys}

Figure 3 shows the XRD results of the modified $\mathrm{Mg}-5 \mathrm{Sn}-1 \mathrm{Si}$
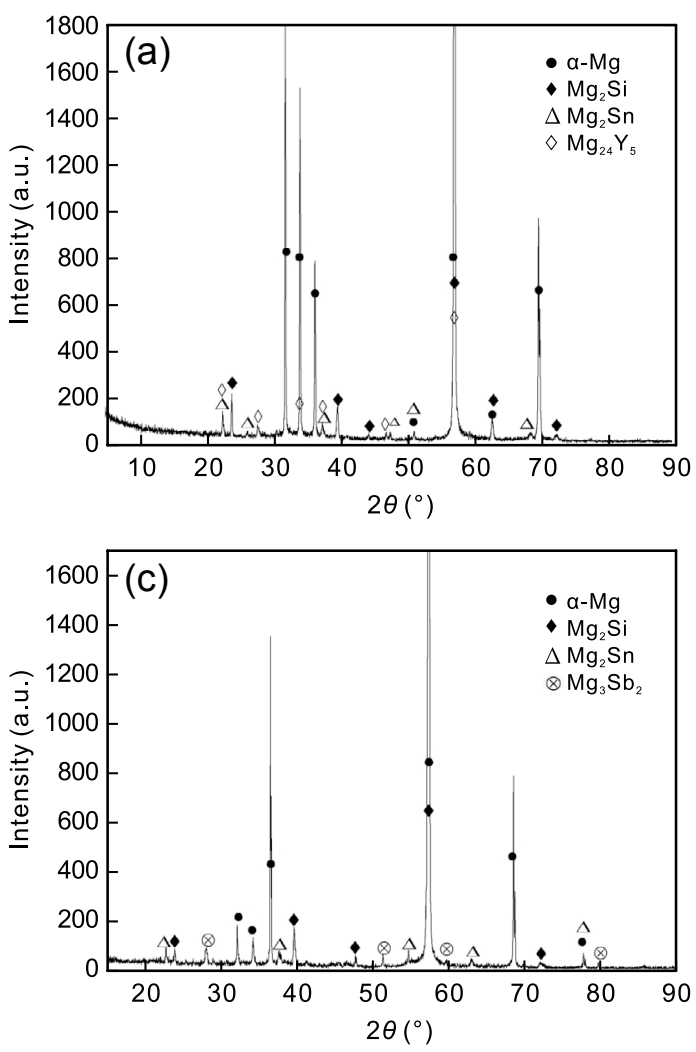

Fig. 3: XRD patterns of modified Mg-5Sn-1Si alloys with $0.8 w t . \% \mathrm{Y}(\mathrm{a}), 0.3 w t . \% \mathrm{Bi}(\mathrm{b}), 0.9 w t . \% \mathrm{Sb}$ (c), and $0.9 w t . \% \mathrm{Sr}$ (d)

After adding trace elements to $\mathrm{Mg}-5 \mathrm{Sn}-1 \mathrm{Si}$ alloy, the microstructures are changed obviously: the matrix grain sizes of the modified alloys are refined. For the $\mathrm{Mg}-5 \mathrm{Sn}-1 \mathrm{Si}$ alloys modified with 0.8 wt. \% Y, 0.3wt.\% Bi, 0.9wt.\% Sb, and 0.9wt.\% $\mathrm{Sr}$, their $\alpha-\mathrm{Mg}$ grain sizes are refined from the unmodified 135 $\mu \mathrm{m}$ to about $105 \mu \mathrm{m}, 97 \mu \mathrm{m}, 94 \mu \mathrm{m}$ and $74 \mu \mathrm{m}$, respectively. Meanwhile, the morphology of $\mathrm{Mg}_{2} \mathrm{Si}$ phase in the modified alloys is also different from the unmodified one, although the refinement efficiency on $\mathrm{Mg}_{2} \mathrm{Si}$ phase is different with different trace elements. Figure 4(a) and Fig. 5(a) show the microstructures of Mg-5Sn-1Si-0.8Y alloy. Almost all the $\mathrm{Mg}_{2} \mathrm{Si}$ phases are refined from the previous coarse Chinese script [Fig. 1(a)] into a discontinuous network spread on the matrix. The similar phenomenon can also be found in $\mathrm{Mg}-5 \mathrm{Sn}-1 \mathrm{Si}-0.3 \mathrm{Bi}$ alloy, as shown in Fig. 4(b) and Fig. 5(b). The dendritic arm spacing of $\mathrm{Mg}_{2} \mathrm{Si}$ phase is smaller in $\mathrm{Mg}-5 \mathrm{Sn}-1 \mathrm{Si}-0.3 \mathrm{Bi}$ alloy than that in Mg-5Sn-1Si-0.8Y alloy. This means the refinement efficiency of $\mathrm{Bi}$ on $\mathrm{Mg}_{2} \mathrm{Si}$ is better than that of $\mathrm{Y}$. By adding trace $\mathrm{Sb}$ into $\mathrm{Mg}-5 \mathrm{Sn}-1 \mathrm{Si}$, the massive $\mathrm{Mg}_{2} \mathrm{Si}$ phase is refined

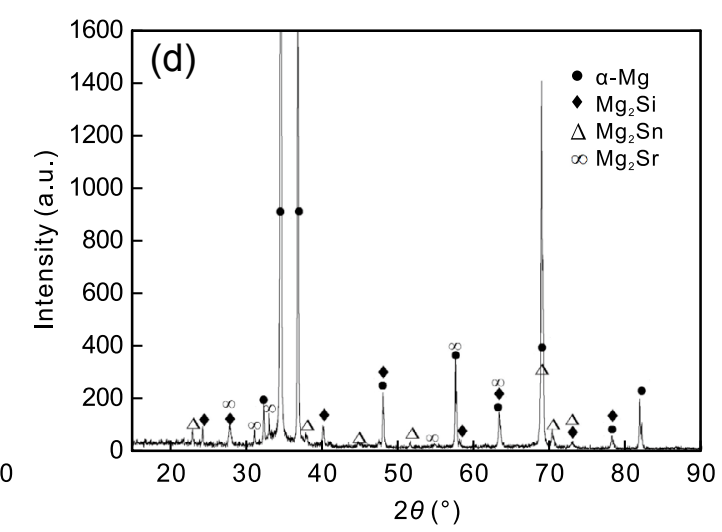

magnesium alloys. It can be found that after adding 0.8wt.\% Y, 0.3wt.\% Bi, 0.9wt.\% Sb and 0.9wt.\% Sr, respectively, to the Mg-5Sn-1Si alloy, except the $\alpha-\mathrm{Mg}, \mathrm{Mg}_{2} \mathrm{Si}, \mathrm{Mg}_{2} \mathrm{Sn}$ and $\mathrm{Mg}_{2}\left(\mathrm{Si}_{x} \mathrm{Sn}_{1-x}\right)$ phases, $\mathrm{Mg}_{24} \mathrm{Y}_{5}, \mathrm{Mg}_{3} \mathrm{Bi}_{2}, \mathrm{Mg}_{3} \mathrm{Sb}_{2}$ and $\mathrm{Mg}_{2} \mathrm{Sr}$ phases, respectively, were found. The OM images of the modified Mg-5Sn-1Si magnesium alloys are shown in Fig. 4 and the corresponding SEM images are shown in Fig. 5. The phase compositions measured with EDS are given in Table 3. This indicates that trace elements can not only change the phase morphology but also influence the phase formation in the modified Mg-5Sn-1Si magnesium alloys.

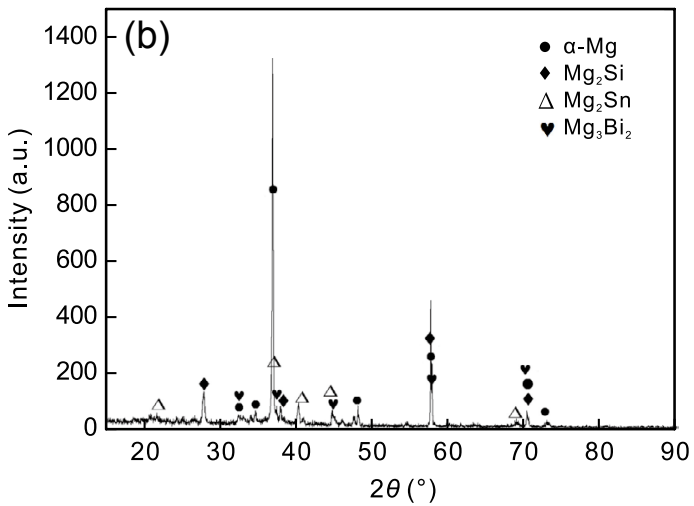

and the coarse Chinese script $\mathrm{Mg}_{2} \mathrm{Si}$ is broken into islands and dispersed at the grain boundaries. For Mg-5Sn-1Si-0.9Sb alloy, an obvious white phase marked as I in Fig. 5(c) can be identified in $\mathrm{Mg}_{2} \mathrm{Si}$ phase. Combining Fig. 3(c) and EDS results in Table 3, it can be concluded that Phase I in Fig. 5(c) is $\mathrm{Mg}_{3} \mathrm{Sb}_{2}$, which is the nucleus of $\mathrm{Mg}_{2} \mathrm{Si}$. Hence, the reason for the modification and refinement of $\mathrm{Mg}_{2} \mathrm{Si}$ phase in $\mathrm{Mg}-5 \mathrm{Sn}-1 \mathrm{Si}-0.9 \mathrm{Sb}$ alloy is strongly related to the heterogeneous nucleation. Meanwhile, the morphology of $\mathrm{Mg}_{2} \mathrm{Si}$ phase in $\mathrm{Mg}-5 \mathrm{Sn}-1 \mathrm{Si}-0.9 \mathrm{Sb}$ alloy is much finer than that in $\mathrm{Mg}-5 \mathrm{Sn}-1 \mathrm{Si}-0.3 \mathrm{Bi}$ alloy. This implies that the modified effect of $\mathrm{Sb}$ on $\mathrm{Mg}_{2} \mathrm{Si}$ phase is greater than that of $\mathrm{Bi}$. For the $\mathrm{Sr}$ alloyed system, the initial Chinese script $\mathrm{Mg}_{2} \mathrm{Si}$ is refined into very fine dendrite shapes distributed on the matrix. This indicates that $\mathrm{Sr}$ has very good refinement effect on $\mathrm{Mg}_{2} \mathrm{Si}$ phase. Comparing the modification effects of the alloys, $\mathrm{Sr}$ has the best refinement effect compared with $\mathrm{Sb}, \mathrm{Bi}$ and $\mathrm{Y}$ elements. Hence, the refinement efficiency sequence of trace elements on magnesium matrix and $\mathrm{Mg}_{2} \mathrm{Si}$ compound in $\mathrm{Mg}-5 \mathrm{Sn}-1 \mathrm{Si}$ alloy is $\mathrm{Sr}$, followed by $\mathrm{Sb}, \mathrm{Bi}$ and $\mathrm{Y}$. 


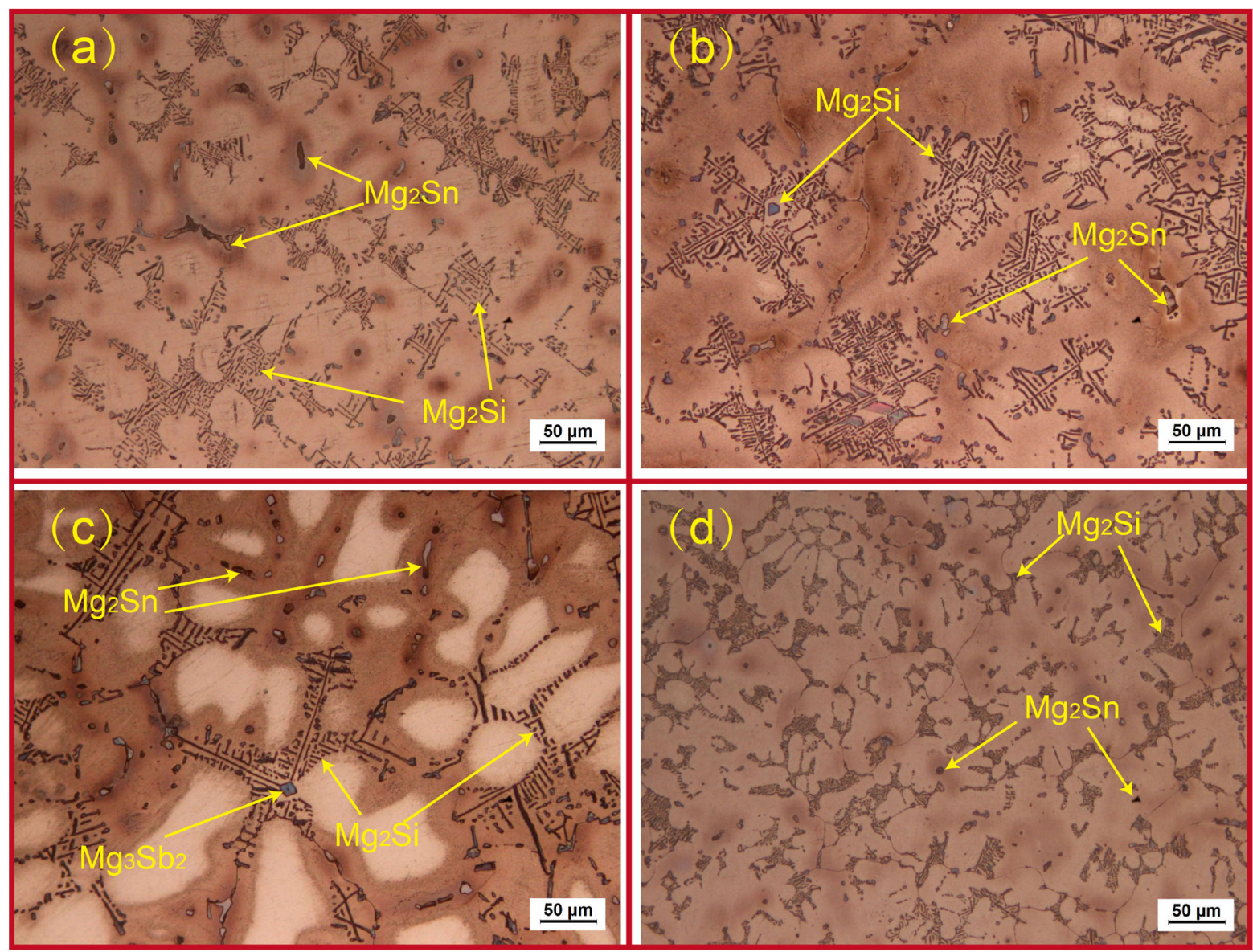

Fig. 4: Optical micrographs of as-cast Mg-5Sn-1Si alloys with $0.8 w t . \%$ Y (a), $0.3 w t . \% \mathrm{Bi}(\mathrm{b}), 0.9 \mathrm{wt} . \% \mathrm{Sb}$ (c), and 0.9 wt. $\%$ Sr (d)

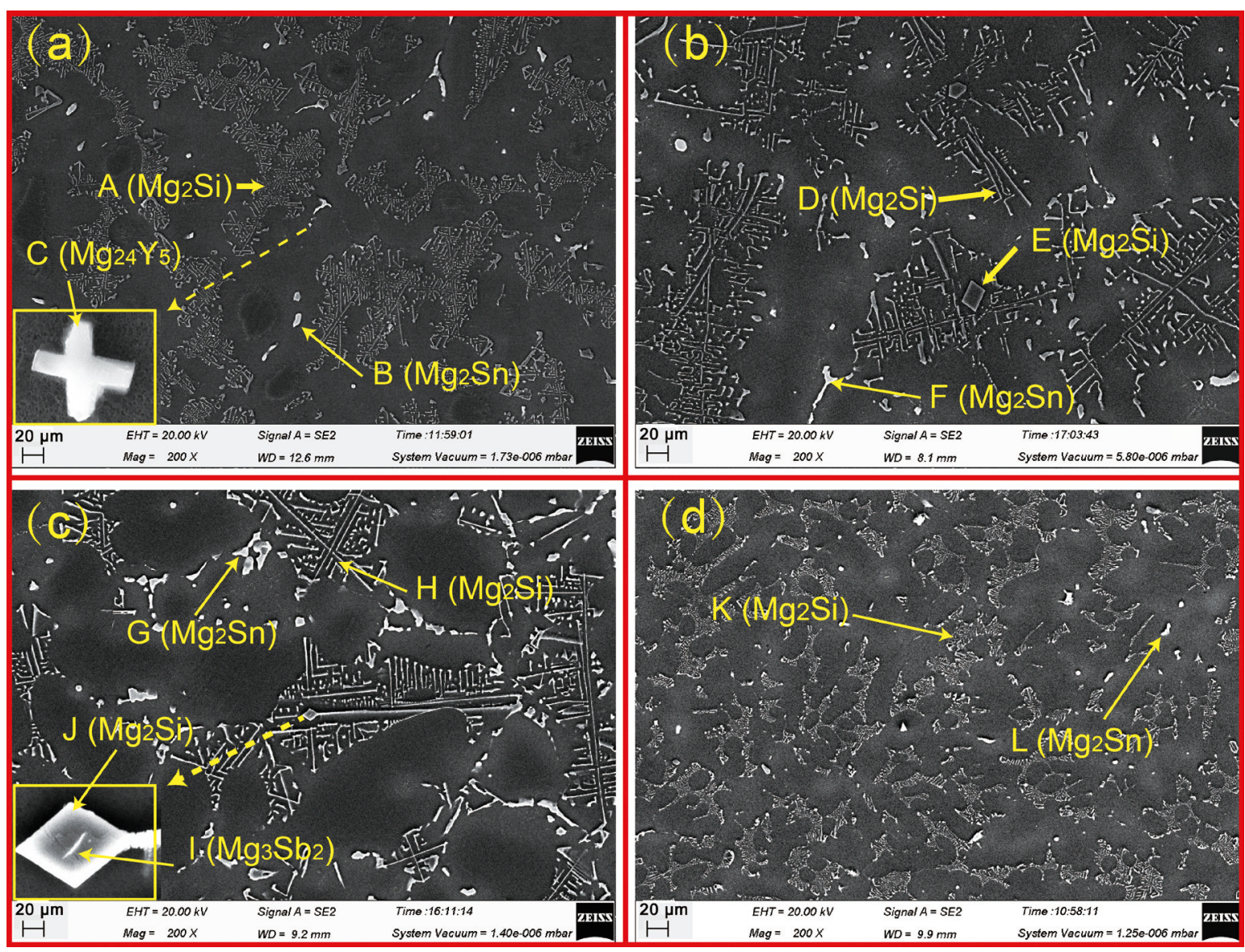

Fig. 5: SEM images of Mg-5Sn-1Si alloyswith $0.8 w t . \%$ Y (a), $0.3 w t . \%$ Bi (b), $0.9 w t . \%$ Sb (c), and 0.9wt.\% Sr (d) 
Table 3: EDS results of experimental alloys (wt.\%)

\begin{tabular}{|c|c|c|c|c|c|c|c|c|}
\hline Alloys & Position & Mg & Sn & Si & $\mathbf{Y}$ & $\mathrm{Bi}$ & $\mathrm{Sb}$ & $\mathrm{Sr}$ \\
\hline \multirow{3}{*}{ Mg-5Sn-1Si-0.8Y } & A & 59.16 & 15.19 & 25.56 & 0.10 & - & - & - \\
\hline & B & 32.52 & 63.97 & 3.33 & 0.18 & - & - & - \\
\hline & C & 39.33 & 5.11 & 14.47 & 41.09 & - & - & - \\
\hline \multirow{3}{*}{ Mg-5Sn-1Si-0.3Bi } & D & 56.54 & 14.41 & 28.12 & - & 0.93 & & \\
\hline & $\mathrm{E}$ & 64.01 & 2.97 & 32.71 & - & 0.31 & - & - \\
\hline & $\mathrm{F}$ & 36.26 & 59.62 & 2.13 & - & 1.99 & - & - \\
\hline \multirow{4}{*}{ Mg-5Sn-1Si-0.9Sb } & G & 31.66 & 59.06 & 0.55 & - & - & 8.73 & \\
\hline & $\mathrm{H}$ & 55.47 & 7.72 & 22.33 & - & - & 14.47 & - \\
\hline & I & 50.11 & 1.32 & 15.54 & - & - & 33.04 & - \\
\hline & $\mathrm{J}$ & 53.20 & 5.50 & 26.24 & - & - & 15.03 & - \\
\hline \multirow{2}{*}{$\mathrm{Mg}-5 \mathrm{Sn}-1 \mathrm{Si}-0.9 \mathrm{Sr}$} & K & 61.23 & 9.40 & 28.59 & - & - & - & 0.78 \\
\hline & L & 33.33 & 64.97 & 1.52 & - & - & - & 0.18 \\
\hline
\end{tabular}

\subsection{Tensile properties}

The tensile properties of the studied alloys are shown in Fig. 6. The ultimate tensile strength (UTS) and elongation to failure of $\mathrm{Mg}-5 \mathrm{Sn}-1 \mathrm{Si}$ alloy under room temperature are $87 \mathrm{MPa}$ and $4 \%$, respectively. The UTS is $96 \mathrm{MPa}$ for $\mathrm{Mg}-5 \mathrm{Sn}-1 \mathrm{Si}-$ $0.8 \mathrm{Y}$ alloy, $108 \mathrm{MPa}$ for Mg-5Sn-1Si-0.3Bi alloy, $117 \mathrm{MPa}$ for $\mathrm{Mg}-5 \mathrm{Sn}-1 \mathrm{Si}-0.9 \mathrm{Sb}$ alloy and $123 \mathrm{MPa}$ for Mg-5Sn-1Si$0.9 \mathrm{Sr}$ alloy, indicating that adding trace elements can improve the tensile properties of the $\mathrm{Mg}-5 \mathrm{Sn}-1 \mathrm{Si}$ alloy. The reasons for the improvement of the tensile properties of the modified alloys are ascribed to the grain refinement and modification of the $\mathrm{Mg}_{2} \mathrm{Si}$ phase by adding the trace elements (Y, Bi, Sb and $\mathrm{Sr}$ ). On the one hand, according to the Hall-Patch formula, grain refinement is very effective in improving the mechanical performance of magnesium alloy. On the other hand, the coarse Chinese script $\mathrm{Mg}_{2} \mathrm{Si}$ has a detrimental effect on the tensile properties of $\mathrm{Mg}-\mathrm{Si}$ alloys. The detrimental effect is related to the micro-cracks nucleated at the keen-edged corners of $\alpha-\mathrm{Mg} / \mathrm{Mg}_{2} \mathrm{Si}$ interfaces. The keen-edged corners are the stress concentration areas. Hence, $\mathrm{Mg}-5 \mathrm{Sn}-1 \mathrm{Si}$ alloy has poor tensile properties. However, after adding trace elements to $\mathrm{Mg}$ 5Sn-1Si alloy, the coarse Chinese script $\mathrm{Mg}_{2} \mathrm{Si}$ of the modified alloys is refined and then the micro-crack nucleation tendency of the modified $\mathrm{Mg}_{2} \mathrm{Si}$ phase decreases. Therefore, the tensile properties of the modified alloys are improved. Besides, it can be observed that the Mg-5Sn-1Si-0.9Sr alloy has the best strengths. Based on the previous discussion of microstructure, Sr has the best refinement effect among the above four alloying elements. Apparently, the tensile properties of the investigated alloys are consistent with the microstructure observation.

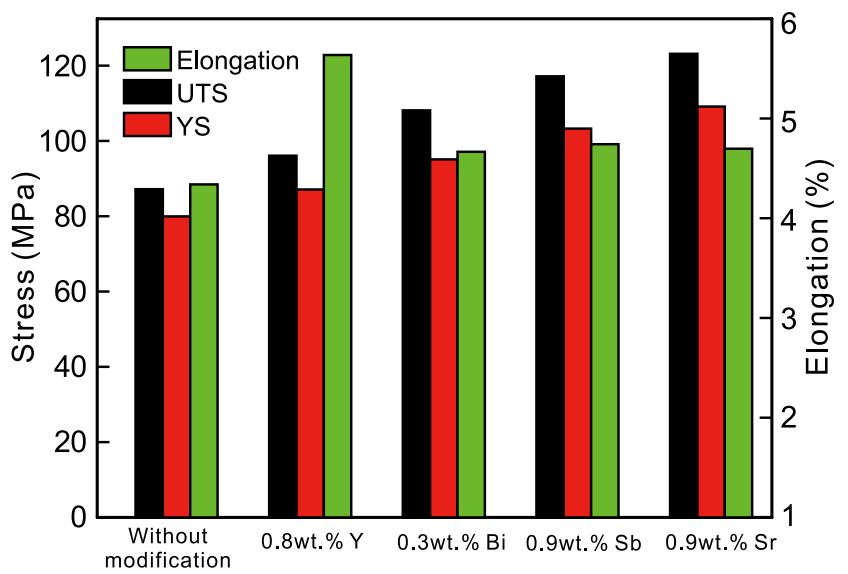

Fig. 6: Tensile properties of Mg-5Sn-1Si alloys modified with different elements

\subsection{Discussion}

Generally, grain refinement in cast $\mathrm{Mg}$ alloys can be achieved through micro-alloying. The refinement is realized by promotion of nucleation rate by manually adding or in situ forming particles, or by restriction of crystal growth by constitutional supercooling, or by both ${ }^{[2]}$. In the present study, since the solubility of each element of $\mathrm{Y}, \mathrm{Bi}, \mathrm{Sb}$ and $\mathrm{Sr}$ in $\alpha-\mathrm{Mg}$ is in trace amount, and the equilibrium partition coefficient of each element is very small, these elements will definitely enrich in the front of the growing crystals through segregation during solidification. The enrichment inevitably results in the change of the crystals' growing environment. If the composition at the site of the growing front can meet the conditional requirement for a new phase to form, the new phase in turn can be as the nucleus to other phases, such as 
$\mathrm{Mg}_{3} \mathrm{Sb}_{2}$ in $\mathrm{Mg}-5 \mathrm{Sn}-1 \mathrm{Si}-0.9 \mathrm{Sb}$ alloy can be as the nucleus of $\mathrm{Mg}_{2} \mathrm{Si}$. If the composition at the growing front cannot meet the conditional requirement for a new phase to form, the solute undercooling is beneficial to grain refinement.

It is now generally accepted that solute undercooling $(\Delta T)$ during solidification process and solute segregation [(quantified by the growth restriction factor (GRF) ${ }^{[34]}$ are critical in determining the final grain size and distribution of the second phase of as-cast magnesium alloys. In order to describe the impact of $\Delta T$ on as-cast grain size, a correlative growth restriction factor (GRF) or $Q$ value is widely used. The $Q_{\text {total }}$ value is simply expressed as:

$$
Q_{\text {total }}=\Sigma m_{i} C_{0, i}\left(k_{i}-1\right)
$$

where $m_{\mathrm{i}}$ is the slope of the liquidus, $C_{0, \mathrm{i}}$ the initial composition of the alloy, and $k_{\mathrm{i}}$ the equilibrium partition coefficient of the solute element ${ }^{[35-38]}$. A greater $Q_{\text {total }}$ value means a higher $\Delta T$ ahead of the growing dendrite and will result in grain refinement. The $Q$ values of the modification elements used in this study have been calculated with a simplified Mg-M binary system (where $M$ represents the modified element) ${ }^{[35]}$ and are listed in Table 4.

Table 4: $Q$ values for solute elements ${ }^{[35]}$

$\begin{array}{ccccc}\text { Elements } & \boldsymbol{m} & \boldsymbol{k} & \boldsymbol{Q}=\boldsymbol{m}(\boldsymbol{k}-\mathbf{1}) & \text { System } \\ \mathrm{Sn} & -2.41 & 0.39 & 1.47 & \text { Mg-Sn eutectic } \\ \mathrm{Si} & -9.25 & 0 & 9.25 & \text { Mg-Si eutectic } \\ \mathrm{Y} & -3.40 & 0.50 & 1.70 & \text { Mg-Y eutectic } \\ \mathrm{Bi} & -1.814 & 0.145 & 1.551 & \text { Mg-Bi eutectic } \\ \mathrm{Sb} & -0.53 & 0 & 0.53 & \text { Mg-Sb eutectic } \\ \mathrm{Sr} & -3.53 & 0.006 & 3.51 & \text { Mg-Sr eutectic }\end{array}$

The $Q_{\text {total }}$ values of the modified alloys are calculated according to Eq. (1) and are listed in Table 5. Therefore, from the view point of GRF, Mg-5Sn-1Si-0.9Sr alloy has the largest $Q_{\text {total }}$ value, so $\mathrm{Sr}$ is the most effective grain refinement element among the studied ones. The calculated result is also in good agreement with the microstructures of the alloys in Fig. 4. The $Q_{\text {total }}$ values for $\mathrm{Mg}-5 \mathrm{Sn}-1 \mathrm{Si}-0.3 \mathrm{Bi}$ and $\mathrm{Mg}-5 \mathrm{Sn}-1 \mathrm{Si}-0.9 \mathrm{Sb}$ alloys are approximately the same (17.06 for Mg-5Sn-1Si-0.3Bi, and 17.07 for $\mathrm{Mg}-5 \mathrm{Sn}-1 \mathrm{Si}-0.9 \mathrm{Sb}$ ); however, by comparing the microstructure and mechanical properties of $\mathrm{Mg}-5 \mathrm{Sn}-1 \mathrm{Si}-0.3 \mathrm{Bi}$ and $\mathrm{Mg}-5 \mathrm{Sn}-1 \mathrm{Si}-0.9 \mathrm{Sb}$ alloys, it is found that Mg-5Sn-1Si$0.9 \mathrm{Sb}$ alloy has much finer microstructure and better properties. The reason is related to the heterogeneous nuclei of $\mathrm{Mg}_{3} \mathrm{Sb}_{2}$ particles [Fig. 5(c)]. As a result, Mg-5Sn-1Si-0.9Sb alloy has finer microstructure, as shown in Fig. 4(c). Mg-5Sn-1Si-0.8Y alloy has a greater $Q_{\text {total }}$ value than Mg-5Sn-1Si-0.3Bi and Mg-5Sn-1Si-0.9Sb. According to the GRF mechanism, Mg5Sn-1Si-0.8Y alloy could have finer microstructure and better performance than $\mathrm{Mg}-5 \mathrm{Sn}-1 \mathrm{Si}-0.3 \mathrm{Bi}$ and $\mathrm{Mg}-5 \mathrm{Sn}-1 \mathrm{Si}-0.9 \mathrm{Sb}$ alloys. However, it can be observed that Mg-5Sn-1Si-0.8Y alloy has a much coarser grain and microstructure than $\mathrm{Mg}$ 5Sn-1Si-0.3Bi and Mg-5Sn-1Si-0.9Sb alloys, indicating that

Table 5: $Q_{\text {total }}$ values for different modified alloys

$\begin{array}{cc}\text { Alloys } & \boldsymbol{Q}_{\text {total }} \\ \text { Mg-5Sn-1Si-0.8Y } & 17.96 \\ \text { Mg-5Sn-1Si-0.3Bi } & 17.06 \\ \text { Mg-5Sn-1Si-0.9Sb } & 17.07 \\ \text { Mg-5Sn-1Si-0.9Sr } & 19.76\end{array}$

the GRF mechanism is not enough to explain the modification and refinement of $\mathrm{Mg}_{2} \mathrm{Si}$ phase in the $\mathrm{Mg}-5 \mathrm{Sn}-1 \mathrm{Si}-0.8 \mathrm{Y}$ alloy. Besides the GRF mechanism, $\Delta T$ is also a very pivotal factor for the microstructural refinement of engineering alloys ${ }^{[39]}$.

According to classic solidification theory, the relationship between critical nucleus radius $\left(r^{*}\right)$ and $\Delta T$ is given by ${ }^{[40]}$ :

$$
r^{*}=2 \delta / \Delta G_{\mathrm{r}}=2 \delta T_{\mathrm{m}} / L_{\mathrm{m}} \Delta T
$$

where $\Delta G_{\mathrm{r}}$ is the variation of volume free energy, $\delta$ the interfacial energy of the unit surface area, $\Delta T=T_{\mathrm{m}}-T_{1}, T_{\mathrm{m}}$ the equilibrium crystallizing temperature, $T_{1}$ the onset crystallizing temperature, and $L_{\mathrm{m}}$ the crystallizing latent heat. According to Eq. (2), with decreasing $T_{1}$, the critical nucleus radius $r^{*}$ decreases, then the nucleation energy of crystal nucleus reduces and the nucleation probability increases, and then results in grain refinement. In order to study the effect of $\Delta T$ on microstructures, the DSC was performed. Figure 7 shows the DSC curves of the experimental alloys. $\mathrm{Mg}-5 \mathrm{Sn}-1 \mathrm{Si}$ magnesium alloy has three endothermic peaks. According to $\mathrm{Mg}-\mathrm{Si}, \mathrm{Mg}-\mathrm{Sn}$ and $\mathrm{Mg}-\mathrm{Sn}$ Si phase diagrams, it can be speculated the crystallization onset temperature of the primary $\alpha-\mathrm{Mg}$ of the alloy is at about $648.9^{\circ} \mathrm{C}$ and the eutectic reaction temperature is about $637.1^{\circ} \mathrm{C}$. After adding modified elements into $\mathrm{Mg}-5 \mathrm{Sn}-1 \mathrm{Si}$ magnesium alloy, the crystallization onset temperatures of the Mg-5Sn-1Si-0.8Y, Mg5Sn-1Si-0.3Bi, Mg-5Sn-1Si-0.9Sb and Mg-5Sn-1Si-0.9Sr alloys decrease to $646.6{ }^{\circ} \mathrm{C}, 641.3{ }^{\circ} \mathrm{C}, 641.1^{\circ} \mathrm{C}$ and $637.4{ }^{\circ} \mathrm{C}$, and the crystallization eutectic reaction temperatures of the modified alloys decrease to $636.9^{\circ} \mathrm{C}, 635.3{ }^{\circ} \mathrm{C}, 634.8^{\circ} \mathrm{C}$ and $631{ }^{\circ} \mathrm{C}$, respectively. Apparently, adding $\mathrm{Y}, \mathrm{Bi}, \mathrm{Sb}$ and $\mathrm{Sr}$ elements into $\mathrm{Mg}-5 \mathrm{Sn}-1 \mathrm{Si}$ increases $\Delta T$ and promotes the refinement of solidification microstructure. The onset crystallizing temperature 

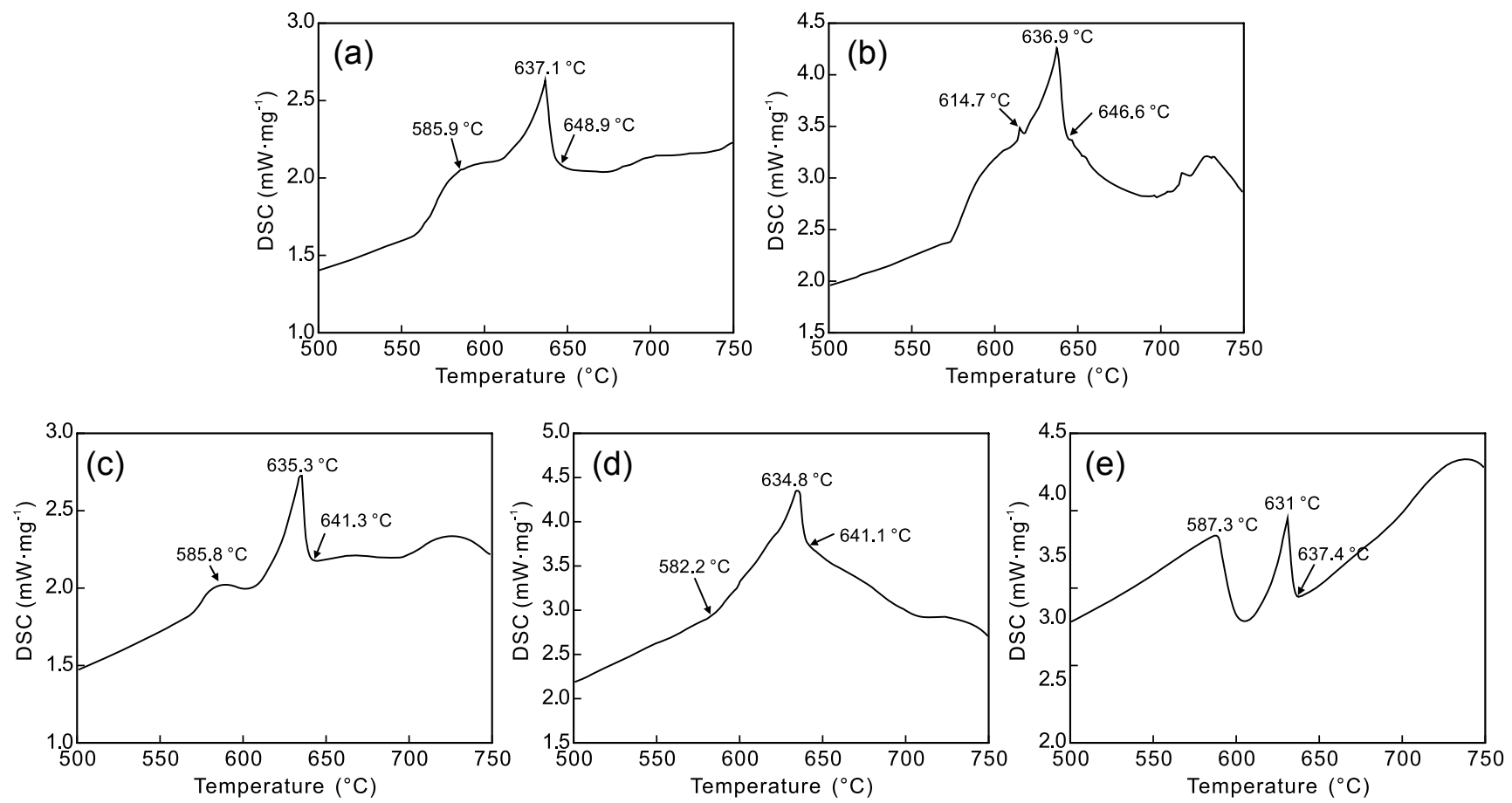

Fig. 7: DSC heating curves of experimental alloys: (a) Mg-5Sn-1Si alloy; (b) Mg-5Sn-1Si-0.8Y alloy; (c) Mg-5Sn-1Si-0.3Bi alloy; (d) Mg-5Sn-1Si-0.9Sb alloy; (e) Mg-5Sn-1Si-0.9Sr alloy

$\left(T_{1}\right)$ of $\mathrm{Mg}-5 \mathrm{Sn}-1 \mathrm{Si}-0.8 \mathrm{Y}$ alloy is higher than that of $\mathrm{Mg}-5 \mathrm{Sn}-$ $1 \mathrm{Si}-0.3 \mathrm{Bi}$ and $\mathrm{Mg}-5 \mathrm{Sn}-1 \mathrm{Si}-0.9 \mathrm{Sb}$ alloys. According to Eq. (2), the $\Delta T$ of Mg-5Sn-1Si- $0.8 \mathrm{Y}$ alloy is smaller than that of the Mg5Sn-1Si-0.3Bi and Mg-5Sn-1Si-0.9Sb alloy. Hence, the critical nucleus radius $r^{*}$ increases, then the nucleation energy of crystal nucleus increases and the nucleation probability decreases. Finally, the Mg-5Sn-1Si-0.8Y alloy shows a much coarser grain size and microstructure. At the same time, Mg-5Sn-1Si-0.9Sr alloy has the lowest crystallization onset temperature. According to Eq. (2), with the decreasing of $T_{1}$, the critical nucleus radius $r^{*}$ decreases, then the nucleation energy of crystal nucleus reduces and the nucleation probability increases, which would result in grain and precipitate refinement. Hence, has the finest microstructure.

Therefore, the refinement mechanism of $\mathrm{Y}, \mathrm{Bi}$ and $\mathrm{Sr}$ elements on Mg-5Sn-1Si magnesium alloy can be explained by both the difference of GRF and the undercooling. For Mg-5Sn$1 \mathrm{Si}-0.9 \mathrm{Sb}$ alloy, the heterogeneous nuclei of $\mathrm{Mg}_{3} \mathrm{Sb}_{2}$ phase is the main reason for refinement.

\section{Conclusions}

In this study, the microstructures and tensile properties of as-cast $\mathrm{Mg}-5 \mathrm{Sn}-1 \mathrm{Si}$ magnesium alloy modified with trace elements $\mathrm{Y}, \mathrm{Bi}, \mathrm{Sb}$ and $\mathrm{Sr}$ are investigated and compared. The following conclusions can be drawn:

(1) The microstructure of as-cast $\mathrm{Mg}-5 \mathrm{Sn}-1 \mathrm{Si}$ alloy consists of $\alpha-\mathrm{Mg}, \mathrm{Mg}_{2} \mathrm{Si}, \mathrm{Mg}_{2} \mathrm{Sn}$ and $\mathrm{Mg}_{2}\left(\mathrm{Si}_{x} \mathrm{Sn}_{1-x}\right)$ phases. After adding trace elements of $\mathrm{Y}, \mathrm{Bi}, \mathrm{Sb}$ and $\mathrm{Sr}$ into $\mathrm{Mg}-5 \mathrm{Sn}-1 \mathrm{Si}$ magnesium alloy, $\mathrm{Mg}_{24} \mathrm{Y}_{5}, \mathrm{Mg}_{3} \mathrm{Bi}_{2}, \mathrm{Mg}_{3} \mathrm{Sb}_{2}$ and $\mathrm{Mg}_{2} \mathrm{Sr}$ phases are precipitated, respectively.
(2) Adding 0.8wt.\% Y, 0.3wt.\% Bi, 0.9wt.\% Sb or 0.9wt.\% $\mathrm{Sr}$ elements into Mg-5Sn-1Si magnesium alloy can refine $\alpha-\mathrm{Mg}$ grain and Chinese script-shaped $\mathrm{Mg}_{2} \mathrm{Si}$. Sr has the most refinement efficiency and $\mathrm{Mg}-5 \mathrm{Sn}-1 \mathrm{Si}-0.9 \mathrm{Sr}$ alloy has the most refined microstructure with a grain size of $74 \mu \mathrm{m}$, and the highest tensile strength of $123 \mathrm{MPa}$.

(3) The refinement mechanism of $\mathrm{Y}, \mathrm{Bi}$ and $\mathrm{Sr}$ elements on Mg-5Sn-1Si magnesium alloy can be explained by the growth restriction factors and the solute undercooling. For Mg-5Sn-1Si$0.9 \mathrm{Sb}$ alloy, the heterogeneous nuclei of $\mathrm{Mg}_{3} \mathrm{Sb}_{2}$ phase is the main reason for the refinement of the grain and second phases.

\section{Acknowledgements}

The authors are grateful for the financial support by the National Natural Science Foundation of China (Nos.: 51571086 and 51271073) and the financial support from the Natural Science Foundation of Henan Polytechnic University (No.: B2010-20).

\section{References}

[1] Yang M P, Pan F S, Shen J, et al. Comparison of Sb and $\mathrm{Sr}$ on modification and refinement of $\mathrm{Mg}_{2} \mathrm{Si}$ phase in AZ61-0.7Si magnesium alloy. Transactions of Nonferrous Metals Society of China, 2009, 19(2): 287-292.

[2] Ali Y, Qiu D, Jiang B, et al. Current research progress in grain refinement of cast magnesium alloys: A review article. Journal of Alloys and Compounds, 2015, 619: 639-651.

[3] Jung J H, Kang D H, Park W, et al. Thermodynamic modeling of the Mg-Si-Sn system. Calphad, 2007, 31(2): 192-200. 
[4] Yu Z P, Yan Y H, Yao J, et al. Effect of tensile direction on mechanical properties and microstructural evolutions of rolled $\mathrm{Mg}-\mathrm{Al}-\mathrm{Zn}-\mathrm{Sn}$ magnesium alloy sheets at room and elevated temperatures. Journal of Alloys and Compounds, 2018, 744: 211-219.

[5] Zhang W L, Li X F, Ding D Y, et al. Microstructure and mechanical properties of $\mathrm{Mg}_{2} \mathrm{Si} / \mathrm{AZ91}$ composites in situ synthesized by using silica fume as the $\mathrm{Si}$ source. Journal of Materials Engineering and Performance, 2018, 27(10): 5300-5311.

[6] Dixit N, Xie K Y, Hemker K J, et al. Microstructural evolution of pure magnesium under high strain rate loading. Acta Materialia, 2015, 87: 56-67.

[7] Zhu S M, Abbott T B, Gibson M A, et al. The influence of minor $\mathrm{Mn}$ additions on creep resistance of die-cast Mg-Al-RE alloys. Materials Science and Engineering: A, 2017, 682: 535-541.

[8] Yu H S, Yang W P, Cui H P, et al. Microstructures and tensile properties of hot-extruded $\mathrm{Mg}-6 \mathrm{Zn}-\mathrm{xCe}(x=0,0.6,1.0,2.0)$ alloys. Journal of Wuhan University of Technology, 2019, 34(1): 150-155.

[9] Yang W P, Guo X F. A high strength Mg-6Zn-1Y-1Ce alloy prepared by hot extrusion. Journal of Wuhan University of Technology-Mater. Sci. Ed., 2013, 28(2): 389-395.

[10] Baghani A, Khalilpour H, Miresmaeili S. The microstructure and impression creep behavior of cast $\mathrm{Mg}-4 \mathrm{Sn}-4 \mathrm{Ca}$ alloy. Materials Science and Engineering: A, 2016, 652: 365-369.

[11] Srinivasan $A$, Dieringa $H$, Mendis $C L$, et al. Creep behavior of Mg-10Gd- $x Z n$ ( $x=2$ and $6 \mathrm{wt} . \%)$ alloys. Materials Science and Engineering: A, 2016, 649: 158-167.

[12] Kozlov A, Gröbner J, Schmid-Fetzer R. Phase formation in Mg-Sn-Si and Mg-Sn-Si-Ca alloys. Journal of Alloys and Compounds, 2011, 509(7): 3326-3337.

[13] Zhang J X, Wang HY, Gao A H, et al. Study on thermodynamics basic and alloy phase evolution of Mg-Sn-Si magnesium alloy. Acta Physica Sinica, 2015, 6: 278-283. (In Chinese)

[14] Zhang M, Zhang W Z, Zhu G Z. The morphology and orientation of $\mathrm{Mn}_{5} \mathrm{Si}_{3}$ precipitates in a Mg-Sn-Mn-Si alloy. Materials Letters, 2008, 62(28): 4374-4376.

[15] Wang Y, Guo X F, Yang W P, et al. Morphology and properties of $\mathrm{Mg}_{2} \mathrm{Si}$ and $\mathrm{Mg}_{2}\left(\mathrm{Si}_{x} \mathrm{Sn}_{1-\chi}\right)$ reinforcements in magnesium alloys. Materials Science and Technology, 2017, 33(15): 1811-1818.

[16] Langelier B, Sha G, Korinek A, et al. The effects of microalloying on the precipitate microstructure at grain boundary regions in an Mg-Zn-based alloy. Materials \& Design, 2017, 119: 290-296.

[17] Yang M B, Pan F S, Shen J, et al. Comparison of Sb and Sr on modification and refinement of $\mathrm{Mg}_{2} \mathrm{Si}$ phase in AZ61-0.7Si magnesium alloy. Transactions of Nonferrous Metals Society of China, 2009, 19(2): 287-292.

[18] Tang S Q, Zhou J X, Tian C W, et al. Morphology modification of $\mathrm{Mg}_{2} \mathrm{Si}$ by $\mathrm{Sr}$ addition in $\mathrm{Mg}-4 \% \mathrm{Si}$ alloy. Transactions of Nonferrous Metals Society of China, 2011, 21(9): 1932-1936.

[19] Hou J, Li C, Liu X F. Nucleating role of an effective in situ $\mathrm{Mg}_{3} \mathrm{P}_{2}$ on $\mathrm{Mg}_{2} \mathrm{Si}$ in Mg-Al-Si alloys. Journal of Alloys and Compounds, 2011, 509(3): 735-739.

[20] Guo E J, Ma B X, Wang L P. Modification of $\mathrm{Mg}_{2}$ Si morphology in $\mathrm{Mg}$-Si alloys with $\mathrm{Bi}$. Journal of Materials Processing Technology, 2008, 206(1-3): 161-166.

[21] Jiang $Q \mathrm{C}$, Wang $\mathrm{H} Y$, Wang $\mathrm{Y}$, et al. Modification of $\mathrm{Mg}_{2} \mathrm{Si}$ in $\mathrm{Mg}-\mathrm{Si}$ alloys with yttrium. Materials Science and Engineering: A, 2005, 392(1-2): 130-135.

[22] Rajeshkumar R, Jayaraj J, Srinivasan A, et al. Investigation on the microstructure, mechanical properties and corrosion behavior of $\mathrm{Mg}-\mathrm{Sb}$ and $\mathrm{Mg}-\mathrm{Sb}-\mathrm{Si}$ alloys. Journal of Alloys and Compounds, 2017, 691: 81-88.
[23] Liao L H, Zhang X Q, Wang $H$ W, et al. Influence of Sb on damping capacity and mechanical properties of $\mathrm{Mg}_{2} \mathrm{Si} / \mathrm{Mg}-9 \mathrm{Al}$ composite materials. Journal of Alloys and Compounds, 2007, 430(1-2): 292-296.

[24] Yang M B, Shen J, Pan F S. Effect of Sb on microstructure of semi-solid isothermal heat-treated AZ61-0.7Si magnesium alloy. Transactions of Nonferrous Metals Society of China, 2009, 19(1): 32-39.

[25] Wang L P, Guo E J, Ma B X. Modification effect of lanthanum on primary phase $\mathrm{Mg}_{2} \mathrm{Si}$ in $\mathrm{Mg}$-Si alloys. Journal of Rare Earths, 2008, 26(1): 105-109.

[26] Hu J L, Tang C P, Zhang X M, et al. Modification of $\mathrm{Mg}_{2} \mathrm{Si}$ in $\mathrm{Mg}$-Si alloys with neodymium. Transactions of Nonferrous Metals Society of China, 2013, 23(11): 3161-3166.

[27] Ye L Y, Hu J L, Tang C P, et al. Modification of $\mathrm{Mg}_{2} \mathrm{Si}$ in Mg-S alloys with gadolinium. Materials Characterization, 2013, 79: 1-6.

[28] Wang $H Y$, Wang W, Zha M, et al. Influence of the amount of $\mathrm{KBF}_{4}$ on the morphology of $\mathrm{Mg}_{2} \mathrm{Si}$ in Mg-5Si alloys. Materials Chemistry and Physics, 2008, 108(2-3): 353-358.

[29] Liu H M, Chen Y G, Tang Y B, et al. The microstructure, tensile properties, and creep behavior of as-cast Mg-(1-10)\%Sn alloys. Journal of Alloys and Compounds, 2007, 440(1-2): 122-126.

[30] Ma J, Guo X F, Wang Y, et al. Influence of trace $Y$ on microstructure of Mg-5Sn-1Si magnesium alloy. Hot Working Technology, 2019, 48(12): 34-39. (In Chinese)

[31] Yan $\mathrm{H}, \mathrm{Hu} Y, \mathrm{Wu} X \mathrm{Q}$, et al. Influence of $\mathrm{Sb}$ modification on microstructures and mechanical properties of $\mathrm{Mg}_{2} \mathrm{Si} / \mathrm{AM} 60$ composites. Transactions of Nonferrous Metals Society of China, 2010, 20(S2): 411-415.

[32] Wang $Y$, Guo $X$ F. Heterogeneous nucleation of $\mathrm{Mg}_{2} \mathrm{Si}$ and $\mathrm{Mg}_{2}(\mathrm{Si}, \mathrm{Sn})$ on $\mathrm{Mg}_{3} \mathrm{Sb}_{2}$ nucleus in $\mathrm{Mg}$ Containing Si alloys. Materials Chemistry \& Physics, 2018.

[33] Cong M Q, Li Z Q, Liu J S, et al. Effect of Sr on microstructure, tensile properties and wear behavior of as-cast Mg- $6 \mathrm{Zn}-4 \mathrm{Si}$ alloy. Materials \& Design, 2014, 53: 430-434.

[34] Xu Y J, Zhao D D, Li Y J. A Thermodynamic Study on the effect of solute on the nucleation driving force, solid-liquid interfacial energy, and grain refinement of Al alloys. Metallurgical and Materials Transactions A, 2018, 49(5): 1770-1781.

[35] David H S, Ma Q, et al. Grain refinement of magnesium alloys. Metallurgical \& Materials Transactions A, 2005, 36, 1669-1679.

[36] Schmid-Fetzer R, Kozlov A. Thermodynamic aspects of grain growth restriction in multicomponent alloy solidification. Acta Materialia, 2011, 59(15): 6133-6144.

[37] Quested T E, Dinsdale A T, Greer A L. Thermodynamic modelling of growth-restriction effects in aluminium alloys. Acta Materialia, 2005, 53(5): 1323-1334.

[38] Men H, Fan Z. Effects of solute content on grain refinement in an isothermal melt. Acta Materialia, 2011, 59(7): 2704-2712.

[39] Yang M B, Pan F S, Cheng R J, et al. Comparison about effects of $\mathrm{Sb}, \mathrm{Sn}$ and $\mathrm{Sr}$ on as-cast microstructure and mechanical properties of AZ61-0.7Si magnesium alloy. Materials Science and Engineering: A, 2008, 489(1-2): 413-418.

[40] Zhao P, Wang Q D, Zhai C Q, et al. Effects of strontium and titanium on the microstructure, tensile properties and creep behavior of AM50 alloys. Materials Science and Engineering: A, 2007, 444(1-2): 318-326. 